\title{
Ingestive behavior of crossbred Santa Inês sheep fed water with different salinity levels ${ }^{1}$
}

\section{Comportamento ingestivo de ovinos mestiços da raça santa inês recebendo água com níveis de salinidade}

\author{
José Helder de Andrade Moura ${ }^{2 *}$; Gherman Garcia Leal de Araujo \\ Edilson Paes Saraiva ${ }^{4}$; Ítalo Reneu Rosas de Albuquerque ${ }^{5}$; \\ Silvia Helena Nogueira Turco ${ }^{6}$; Samir Augusto Pinheiro Costa ${ }^{7}$; \\ Nilmara Mercia Santos ${ }^{7}$
}

\begin{abstract}
The objective of the present study was to evaluate the effect of four water salinity levels on the ingestive behavior of non-castrated crossbred Santa Inês sheep. Thirty-two non-castrated crossbred Santa Inês sheep in feedlot, at seven months of age and initial average weight of $21.76 \pm 1.25 \mathrm{~kg}$, were used in the experiment. The experimental design was completely randomized, with four treatments and eight replicates. Four concentrations of salts in the water fed to the animals were evaluated: low $(640 \mathrm{mg} / \mathrm{l})$; medium $(3,188 \mathrm{mg} / \mathrm{l})$; high $(5,740 \mathrm{mg} / \mathrm{l})$ and very high $(8,326 \mathrm{mg} / \mathrm{l})$ levels of total dissolved solids (TDS). For the ingestive behaviors, the animals were observed every ten minutes, for 24 hours, to determine the time spent feeding, ruminating and idle. Also, cud chewing and the average number of defecations and urinations and the frequency of water ingestion were determined. The time spent feeding, ruminating and idle were not changed by the salinity levels in the water. Dry matter intake, neutral detergent fiber intake, total chewing time, total cud chews per day, number of daily meals, average duration of each meal and number of defecations per day did not change either. However, feeding and rumination efficiency in grams of $\mathrm{DM} / \mathrm{h}$, water intake and number of urinations were linearly affected, whereas the variables rumination efficiency in grams of NDF/h, grams of dry matter per cud, grams of neutral detergent fiber per cud, number of cuds, number of chews per cud and chewing time per cud presented quadratic effect. The different levels of total dissolved solids $(640 ; 3,188 ; 5,740$; and $8.326 \mathrm{mg} / \mathrm{l})$ in the water fed to the sheep did not cause alterations in their ingestive behavior. In conclusion, water with up to $8,326 \mathrm{mg} \mathrm{TDS} / 1$ can be an alternative strategic and seasonal method to water crossbred Santa Ines sheep.
\end{abstract}

Key words: Defecation. Rumination. Idleness.

\footnotetext{
${ }^{1}$ Dissertação de mestrado do primeiro autor. Projeto Financiado pelo BNDS/CNPq.

2 Mestre em Zootecnia pelo Programa de Pós-Graduação em Zootecnia, Universidade Federal da Paraíba, UFPB, Areia, PB, Brasil. E-mail: josehelderztc@hotmail.com

3 Pesquisador da Embrapa Semiárido, Bolsista PQ/CNPq, Petrolina, PE, Brasil. E-mail: ghermangarcia@hotmail.com

${ }^{4}$ Prof., Departamento de Zootecnia do Centro de Ciências Agrárias, UFPB, Areia, PB, Brasil. E-mail: edilson@cca.ufpb.br

5 Discente de Doutorado do Programa de Pós-Graduação em Ciência Animal nos Trópicos, Universidade Federal da Bahia, UFBA, Salvador, BA, Brasil. E-mail: italoreneu@hotmail.com

${ }^{6}$ Prof., Programa de Pós-Graduação em Ciência Animal, Universidade Federal do Vale do São Francisco, UNIVASF, Petrolina, PE, Brasil. E-mail: silvia.turco@univasf.edu.br

7 Mestres do Programa de Pós-Graduação em Ciência Animal, UNIVASF, Petrolina, PE, Brasil. E-mail: samiraugusto@terra.com. br; nilmara2000@yahoo.com.br

* Author for correspondence
} 


\section{Resumo}

O presente estudo teve como objetivo avaliar o efeito dos níveis de salinidade da água de consumo sobre o comportamento ingestivo de ovinos inteiros mestiços da raça Santa Inês, criados no semiárido Nordestino Brasileiro. O experimento foi conduzido no setor de metabolismo animal, pertencente a Embrapa Semiárido, localizada em Petrolina/PE, situada na região Nordeste do país. Foram utilizados 32 ovinos inteiros mestiços da raça Santa Inês em confinamento, com idade de sete meses e peso corporal médio inicial de $21,76 \pm 1,25 \mathrm{Kg}$. O delineamento experimental utilizado foi o inteiramente casualizado, com quatro tratamentos e oito repetições. Foram avaliados quatro teores de sais na água de beber dos animais: 640 - baixo; 3.188 - médio; 5.740 - alto e $8.326 \mathrm{mg} / 1$ - muito alto de sólidos dissolvidos totais (SDT). Para o comportamento ingestivo foram realizadas observações a cada dez minutos, durante 24 horas, para determinação do tempo despendido em alimentação, ruminação e ócio. Além da determinação da mastigação merícica e número médio de defecação, micção e frequência de ingestão de água. O tempo despendido com alimentação, ruminação e ócio não sofreram alteração com os níveis de salinidade na água, assim como o consumo de matéria seca, consumo de fibra em detergente neutro, tempo de mastigação total, número de mastigação merícica por dia, número de refeição diária, duração média de cada refeição e o número de vezes de defecação por dia. Contudo, as eficiências de alimentação e ruminação em gramas de $\mathrm{MS} / \mathrm{h}$, o consumo de água ofertado, número de vezes de micção e ingestão de água, tiveram efeitos lineares, enquanto as variáveis: eficiência de ruminação em gramas de FDN/h, gramas de matéria seca por bolo, gramas de fibra em detergente neutro por bolo, número de bolos ruminais, número de mastigação merícica por bolo e tempo de mastigação merícica por bolo apresentaram efeitos quadráticos. Os diferentes níveis de sólidos dissolvidos totais $(640,3.188,5.740$ e $8.326 \mathrm{mg} / \mathrm{l} \mathrm{SDT}$ ), presente na água de beber de ovinos não promoveu alterações no comportamento ingestivo. Conclui-se que, águas com até $8.326 \mathrm{mg}$ SDT/1 podem ser uma alternativa de uso estratégico e sazonal para a dessedentação de ovinos mestiços da raça Santa Inês criados na região semiárida do Nordeste brasileiro.

Palavras-chave: Defecação. Ruminação. Ócio.

\section{Introduction}

Scarcity or lack of drinking water for human and animal consumption is one of the main obstacles to the survival and improvement of the quality of life in rural populations of arid and semi-arid regions. In rural areas, it is common to find men and animals sharing the same source of water, which compromises not only the quality of this water but also aggravates the health problem of the man of the country.

Long have solutions to the problem of water availability in the Brazilian Northeast semi-arid region been studied, but it appears that the adopted measures have not solved the problem. Digging wells in semi-arid regions is one of the many attempts to minimize the water-scarcity problem; however, this practice is associated with problems related to salinity of groundwaters (PORTO et al., 1997).
The groundwater found in the Brazilian Northeast semi-arid region is highly variable, containing water with different mineral concentrations, which range from 0.00002 or $0.0128 \mathrm{mg} / 1$ of TDS to $75 \mathrm{dS} / \mathrm{m}$ or $48,000 \mathrm{mg} / 1$ of TDS (CPRM, 2012), and good quality regarding the electric conductivity; and saline waters, which are improper for human consumption. These unsuitable waters for consumption can be utilized to water animals in times of scarcity or even under water shortages, so it is necessary to know the maximum concentration of salts animals can tolerate in these saline waters found in artesian wells in the Brazilian Northeast.

Small ruminants, especially sheep and goat, play important social and economic roles in many nations, especially in the semi-arid region of the Brazilian Northeast, due to their adaptive characteristics to adverse environmental conditions 
and good efficiency in using water. However, the adequate supply of water in animal production is important so as to meet the requirements of the animals and maintain their welfare, which promotes their development and weight gain.

Studying the ingestive behavior is an important tool for evaluating the animal response to certain diets, because it allows for understanding the factors acting on the regulation of the intake of feed and water, thus making it possible to establish adjustments in the feeding management of animals aiming at better productive performance (CARVALHO et al., 2004; MENDONÇA et al., 2004). Therefore, strategies in the elaboration of diets, to meet the different production systems, in the arid and semi-arid environments, are of utmost importance, since these regions present low forage availability and one of the most scarce essential elements for life is water.

Given the above, the objective of this study is to evaluate the effect of water salinity levels on the ingestive behavior of uncastrated crossbred Santa Inês sheep.

\section{Materials and Methods}

\section{Local and animals}

The experiment was conducted in the Animal Metabolism Sector of the Experimental Caatinga Field of Empresa Brasileira de Pesquisa Agropecuária (EMBRAPA), located in the municipality of Petrolina/PE, Brazil, in the semiarid region. The climate is classified, according to Köppen, as Bsh'w, with average annual precipitation of $570 \mathrm{~mm}$ and average maximum and minimum annual temperatures of 33.46 and 20.87 ${ }^{\circ} \mathrm{C}$, respectively (EMBRAPA, 2011).

Thirty-two uncastrated, crossbred, confined Santa Ines sheep with approximate age of seven months and average initial weight of $21.76 \pm 1.25$ $\mathrm{kg}$ were used; the animals were originally from farms of the region. The experimental design was completely randomized, with four treatments and eight replications, in which each animal was a replicate. The experimental period was 75 days, of which 12 were used for the animals to acclimate, and 63 days to collect the data, when the animals remained in a shed provided with feeding and drinking troughs.

\section{Treatments}

The experimental treatments consisted of waters with different levels of total dissolved solids (TDS): 640; 3,188; 5,740; and 8,326 mg/l, obtained using sodium chloride $(\mathrm{NaCl})$, electrical conductor of $1,5,9$ and $13 \mathrm{dS} / \mathrm{m}$. To obtain the levels of $\mathrm{mg} / \mathrm{l}$ of total dissolved solids, the unit 640 , equivalent to $1 \mathrm{dS} / \mathrm{m}$, was used, according to Marwick (2007).

The solutions were prepared in four water tanks, utilizing a source of water from the water-supply system of Embrapa do Rio São Francisco, without chemical treatments, in which sodium chloride without iodine - commonly found in the market -was added to reach the electrical conductivity desired. The conductivities of the water from each treatment were read daily with a conductivity meter manufactured by Digimed ${ }^{\circledR}$, allowing for a difference of $5 \%$ from the limit of each treatment.

During the entire experiment, samples of water from each treatment were collected weekly and conditioned in labeled plastic bags and subsequently frozen until they were analyzed. The samples were sent to the Geo-Environmental Laboratory of Embrapa Semiárido, where chemical analyses for bicarbonate, chlorides, calcium, magnesium, potassium and sodium were conducted, and where the electrical conductivity, temperature and $\mathrm{pH}$ of the collected waters were also measured (Table 1). 
Feeding and experimental development

The diet utilized in the experiment was common for all treatments; it was composed of $50 \%$ of buffel-grass (Cenchrus ciliares) hay and 50\% concentrate, which consisted of $69.31 \%$ ground corn, $29.79 \%$ soybean and $0.9 \%$ mineral mix. The diet contained the same amount of nitrogen and energy, on a dry-matter basis, to provide gains of up to $200 \mathrm{~g} /$ day (NRC, 2007); it was supplied twice daily, at $09 \mathrm{~h} 00$ and $15 \mathrm{~h} 00$. The amount offered was calculated based on the intake of the previous day, always considering orts of $10 \%$. Samples of the feed supplied and orts were collected weekly and chemically analyzed at the laboratory.

Table 1. Mean values of the variables conductivity, total dissolved solids, $\mathrm{pH}$, temperature, sodium, chlorine, calcium, magnesium, potassium and alkalinity of the waters offered to experimental sheep.

\begin{tabular}{lcccc}
\hline \multirow{2}{*}{ Variables } & \multicolumn{3}{c}{ Total dissolved solids in the water $(\mathrm{mg} / \mathrm{l})$} \\
\cline { 2 - 4 } & 640 & 3,188 & 5,740 & 8,326 \\
\hline Conductivity $(\mathrm{dS} / \mathrm{m})$ & 1.00 & 4.98 & 8.97 & 13.01 \\
Total dissolved solids $(\mathrm{g} / \mathrm{l})$ & 0.64 & 3.18 & 5.74 & 8.32 \\
$\mathrm{pH}$ & 8.02 & 8.09 & 8.09 & 8.11 \\
Temperature $\left({ }^{\circ} \mathrm{C}\right)$ & 25.60 & 25.15 & 24.70 & 24.86 \\
Sodium $(\mathrm{mg} / \mathrm{l})$ & 230.00 & 805.00 & 1.725 .00 & 2.415 .00 \\
Chlorine $(\mathrm{mg} / \mathrm{l})$ & 490.72 & 1.898 .34 & 2.892 .72 & 4.519 .87 \\
Calcium $(\mathrm{mg} / \mathrm{l})$ & 17.56 & 23.04 & 27.41 & 36.02 \\
Magnesium $(\mathrm{mg} / \mathrm{l})$ & 12.51 & 18.48 & 24.86 & 26.23 \\
Potassium $(\mathrm{mg} / \mathrm{l})$ & 2.71 & 3.32 & 3.52 & 4.10 \\
Alkalinity $(\mathrm{mg} / \mathrm{l})$ & 30.40 & 29.45 & 27.00 & 31.20 \\
\hline
\end{tabular}

\section{Laboratory methods}

All the samples were analyzed according to the methodology described by the AOAC (1990) for dry matter (DM), crude protein (CP), organic matter $(\mathrm{OM})$, ether extract (EE), acid detergent fiber (ADF) and lignin. In the analysis of neutral detergent fiber
(NDF), the samples were treated with thermostable alpha-amylase, without using sodium sulfide, and corrected for ash (MERTENS, 1992). The correction of NDF and ADF for the nitrogen compounds and estimate of the neutral and acid detergent insoluble nitrogen compounds were performed according to Licitra et al. (1996) (Table 2).

Table 2. Chemical composition of the ingredients of the buffel grass-based diet and corn- and soybean-based concentrate offered to experimental sheep.

\begin{tabular}{lcccc}
\hline \multicolumn{1}{c}{ Components (\%) } & Buffel grass hay & Soybean meal & Ground corn & Diet (50:50) \\
\hline Dry matter & 85.20 & 85.80 & 85.80 & 85.08 \\
Organic matter & 88.30 & 93.10 & 94.87 & 90.90 \\
Mineral matter & 11.70 & 6.92 & 5.13 & 9.10 \\
Crude protein & 4.81 & 49.10 & 10.10 & 13.00 \\
Ether extract & 1.31 & 1.62 & 3.58 & 1.92 \\
NDFap & 71.87 & 15.16 & 18.73 & 44.68 \\
Acid detergent fiber & 47.90 & 6.42 & 5.39 & 26.41 \\
\hline
\end{tabular}




\begin{tabular}{lcccc} 
& & & $\ldots$ Continuation \\
\hline Total carbohydrates & 82.20 & 42.30 & 81.20 & 77.73 \\
NFC $^{4}$ & 7.07 & 26.90 & 61.80 & 32.45 \\
Hemicellulose & 27.10 & 8.97 & 13.90 & 18.87 \\
ADIN $^{5}$ & 0.36 & 0.48 & 0.70 & 0.50 \\
NDIN $^{6}$ & 0.30 & 0.96 & 0.95 & 0.63 \\
Lignin & 11.33 & 3.10 & 1.85 & 6.76 \\
TDN $^{7}$ & $32.25^{2}$ & $82.00^{1}$ & $85.00^{1}$ & $57.78^{1}$ \\
\hline
\end{tabular}

${ }^{1}$ Valadares Filho et al. (2006). ${ }^{2}$ Moreira et al. (2006).

${ }^{3}$ Neutral detergent fiber corrected for ash and protein; ${ }^{4}$ Non-fibrous carbohydrates. ${ }^{5}$ Acid detergent indigestible nitrogen. ${ }^{6}$ Neutral detergent indigestible nitrogen. ${ }^{7}$ Total digestible nutrients.

\section{Determining the feeding behavior}

To determine the ingestive behavior, the times spent feeding, ruminating and idle were recorded, also continuously observing the number of times the animal defecated, urinated and sought water. Seeking water was recorded as the number of times the animal reached the trough and ingested water, adopting visual observation of the animals at every ten minutes, for 24 hours, which was performed by trained observers in an alternation system, strategically positioned so as not to promote changes in the routine of the animals. On the same day, the number of cud chews ( $\mathrm{n} / \mathrm{cud}$ ) and time spent per cud (s/cud) were counted with digital stopwatches. To obtain the average number of chews and the time, three cuds were observed in four different times of the day (12:00, 18:00, 00:00 and 16:00 h). The time and number of chews for every cud were recorded per animal.

The results regarding the ingestive behavior factors were obtained as follows:

$$
\begin{aligned}
& \mathrm{FE}=\mathrm{DMI} / \mathrm{FT} ; \\
& \mathrm{RE}=\mathrm{DMI} / \mathrm{RT} ; \\
& \mathrm{RE}=\mathrm{NDFI} / \mathrm{RT} ; \\
& \mathrm{TCT}=\mathrm{FT}+\mathrm{RT} ; \\
& \mathrm{NC}=\mathrm{RT} / \mathrm{CTD} ; \\
& \mathrm{NCCD}=\mathrm{NC} \times \mathrm{NCC} ; \\
& \mathrm{GDM}_{\text {cud }}=\mathrm{DMI} / \mathrm{NC} ;
\end{aligned}
$$

$\mathrm{GNDF}_{\text {cud }}=\mathrm{NDFI} / \mathrm{NC}$;

$\mathrm{NDM}=$ number of daily meals; and

ADEM = average duration of each meal, where:

$\mathrm{FE}(\mathrm{g} \mathrm{DM} / \mathrm{h})=$ feeding efficiency, DMI (g DM/ day $)=$ dry matter intake, FT (h/day) = feeding time, $\mathrm{RE}(\mathrm{g} \mathrm{DM} / \mathrm{h})=$ rumination efficiency, $\mathrm{RT}$ (h/day) $=$ rumination time, $\mathrm{TCT}(\mathrm{h} /$ day $)=$ total chewing time, $\mathrm{NC}(\mathrm{n} /$ day $)=$ number of cuds, CTC $(\mathrm{s} /$ cud $)=$ chewing time per cud (POLLI et al., 1996), NCCD $(\mathrm{n} /$ day $)=$ number of cud chews per day, NCC (n/ cud) = number of chews per cud (BÜRGER et al., 2000); $\mathrm{GDM}_{\text {cud }}=$ grams of DM per cud, GNDF ${ }_{\text {cud }}$ = grams of NDF per cud, NDM = number of daily meals and ADEM = average duration of each meal (CARVALHO et al., 2004).

To calculate NDM and ADEM, only meals which lasted five or more minutes were taken into account, aiming to minimize errors of observation or from psychogenic traits of the animals, which at the moment of observation could be just smelling or biting the food, but these might not represent a meal. During the data collection, at the nocturnal observation of the animals, the environment was kept under artificial illumination.

\section{Statistical analysis}

The results were subjected to regression analysis on the SAS 9.0 software (2003). 


\section{Results and Discussion}

The water salinity levels had no influence on the behavioral parameters (Table 3), which can be explained by the fact that confined animals tend to present similar behavior, due to the permanence in individual pens, and by the similarity between nutrient sources in the diets (NOMURA, 2008) fed during the experimental periods, which contained the same ingredients, and the same protein and NDF concentrations. Alterations in the feeding, rumination and idle activities can be often verified in studies where the experimental diets vary in the fiber contents, as observed in an experiment conducted by Carvalho et al. (2006), who supplied increasing levels of NDF from the forage in diets for dairy goats and found increase in the feeding and rumination times and decrease in the idle time.

Table 3. Mean times spent feeding, ruminating and idling by experimental sheep.

\begin{tabular}{|c|c|c|c|c|c|c|}
\hline \multirow{2}{*}{ Variable } & \multicolumn{4}{|c|}{ Total dissolved solids (mg/l) } & \multirow{2}{*}{ Effect } & \multirow{2}{*}{$\mathrm{CV}(\%)$} \\
\hline & 640 & 3,188 & 5,740 & 8,326 & & \\
\hline Feeding (min/h) & 4.61 & 4.41 & 4.76 & 4.30 & $\mathrm{NS}^{1}$ & 12.80 \\
\hline Rumination $(\mathrm{min} / \mathrm{h})$ & 7.46 & 6.97 & 7.52 & 7.15 & NS & 14.15 \\
\hline Idling $(\min / \mathrm{h})$ & 11.93 & 12.62 & 11.72 & 12.55 & NS & 10.24 \\
\hline
\end{tabular}

${ }^{1}$ Not significant.

In Figure 1 we can observe that during the daily period, for all experimental treatments, the animals showed higher feeding peaks, with 25 and $30 \%$ for the periods of 06:00 to $11: 00 \mathrm{~h}$ and 12:00 to $17: 00 \mathrm{~h}$, respectively, during 24 hours, which corresponded to the times of feed supply, which were precisely at 09:00 and 15:00 h. This is in agreement with the reports of Abijaoude et al. (2000), who claimed that, in general, ruminants (goat, sheep and cattle) present two long feeding periods during the day, especially when kept confined. These results also corroborate Mendes Neto et al. (2007), who also supplied a diet twice daily and observed that the ingestion period $(75.68 \%)$ was longer during the day.

Over the 24 hours of the day, the animals preferred to ruminate in the early morning (00:00 to $05: 00 \mathrm{~h}$ ), because this was the time when the air temperatures were lowest, which promoted lower production of endogenous heat coupled to the rumination process. Another period of the day with higher percentage of rumination, although with lower intensity than the former, was the beginning of the day, from 06:00 to 11:00 $\mathrm{h}$, which was exactly the period between the two daily meals. These results are in line with those obtained by Souza et al. (2010), who worked with goats without defined breed and Santa Ines sheep and verified a more consistent rumination activity during early morning and beginning of the day for both studied species.

For the percentage of time idle, during the 24 hours of the day, the animals stayed idle longer from 00:00 to $05: 00 \mathrm{~h}$ and $18: 00$ to $23: 00 \mathrm{~h}$, averaging approximately 60 and $65 \%$, respectively, whereas for the daylight period the sheep showed shorter idle time, which was practically similar for all the studied treatments. 
Figure. 1. Percentages of time spent feeding, ruminating and idling in $24 \mathrm{~h}$ by experimental sheep.

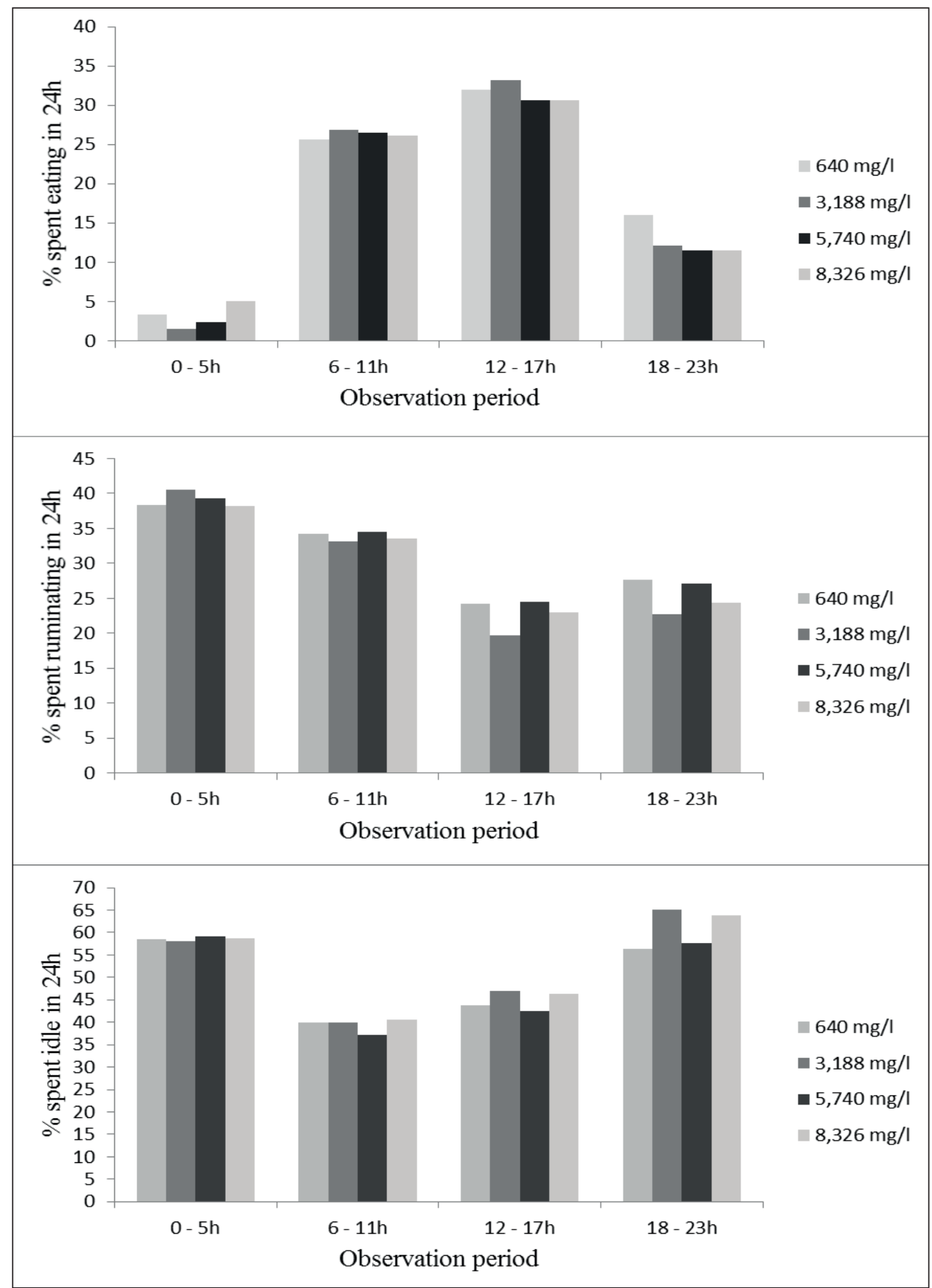

The water intake via trough showed increasing linear effect, as can be observed in Table 4. This is due to the concentrations of less toxic total dissolved solids present in the water, which can increase its intake without harming the animal physiology, due to the capacity of these animals to adapt to saline water (BOYLES, 2009).

According to the NRC (1985), cited by NRC (2007), the total water intake (TWI) can be determined by the equation TWI $=3.86 \times$ DMI - 
0.99, which does not consider the different salinity levels in the water, which tend to increase the water intake by the animals. However, the water intake of the sheep was different when applied to the equation, and the animals showed an average intake of 2,010 g/day, with large variation between the treatments, whereas the intake recommended by the NRC (2007) is 2,540 g/animal/day. These results indicate that even increasing the salinity in the water fed to these animals, they showed lower water intake than recommended by the NRC (2007), which demonstrates the adaptability of Santa Ines sheep to consume saline waters.

Table 4. Intakes of water (WI), daily dry matter (DMI) and neutral detergent fiber (NDFI), feeding efficiency (FE) and rumination efficiency (RE) of dry matter and neutral detergent fiber, and grams of DM $\left(\mathrm{GDM}_{\mathrm{Cud}}\right)$ and NDF $\left(\mathrm{GNDF}_{\mathrm{Cud}}\right)$ per cud observed in experimental sheep.

\begin{tabular}{|c|c|c|c|c|c|c|c|}
\hline \multirow{2}{*}{ Variable } & \multicolumn{4}{|c|}{ Total dissolved solids (mg/l) } & \multirow{2}{*}{ Effect } & \multirow{2}{*}{$\mathrm{R}^{2}$} & \multirow{2}{*}{$\mathrm{CV}(\%)$} \\
\hline & 640 & 3,188 & 5,740 & 8,326 & & & \\
\hline WI (g/day) & 1.520 & 1.640 & 2.290 & 1.960 & $\mathrm{~L}^{1,4}$ & 0.54 & 20.30 \\
\hline DMI (g/day) & 847 & 778 & 1.109 & 923 & $\mathrm{NS}^{2}$ & NS & 18.14 \\
\hline NDFI (g/day) & 299 & 267 & 382 & 322 & NS & NS & 19.29 \\
\hline $\mathrm{FE}(\mathrm{g} D M / \mathrm{h})$ & 191.35 & 185.55 & 246.2 & 250.84 & $\mathrm{~L}^{5}$ & 0.78 & 13.55 \\
\hline RE (g DM/h) & 126.06 & 122.03 & 160.01 & 140.34 & $\mathrm{~L}^{6}$ & 0.36 & 14.40 \\
\hline $\mathrm{RE}(\mathrm{g} N \mathrm{ND} / \mathrm{h})$ & 34.08 & 41.88 & 55.11 & 48.76 & $Q^{3,7}$ & 0.87 & 14.45 \\
\hline $\mathrm{GDM}_{\mathrm{Cud}}(\mathrm{g} / \mathrm{cud})$ & 1.6 & 1.79 & 2.55 & 1.95 & $\mathrm{Q}^{8}$ & 0.63 & 15.31 \\
\hline $\operatorname{GNDF}_{\text {Cud }}(\mathrm{g} / \mathrm{cud})$ & 0.43 & 0.61 & 0.88 & 0.68 & $\mathrm{Q}^{9}$ & 0.84 & 15.73 \\
\hline
\end{tabular}

${ }^{1}$ Linear effect. ${ }^{2}$ Not significant. ${ }^{3}$ Quadratic effect.

${ }^{4} \mathrm{~L}=0.1993 \mathrm{x}+1.3544 .{ }^{5} \mathrm{~L}=5.978 \mathrm{x}+176.64 .{ }^{6} \mathrm{~L}=2.0205 \mathrm{x}+122.97 .{ }^{7} \mathrm{Q}=0.2211 \mathrm{x}^{2}+4.5271 \mathrm{x}+28.524 .{ }^{8} \mathrm{Q}=-0.0123 \mathrm{x}^{2}+0.2181 \mathrm{x}$ $+1.2993 .{ }^{9} \mathrm{Q}=-0.0059 \mathrm{x}^{2}+0.1086 \mathrm{x}+0.2993$.

There was no significant effect for the variables dry matter intake and neutral detergent fiber intake (g/day) in the crossbred Santa Inês sheep fed water with $640 ; 3,188 ; 5,740$; and $8,326 \mathrm{mg} / 1$ of total dissolved solids (Table 4).

The results indicate that saline waters with up to $8.326 \mathrm{mg} / 1$ do not affect the DM or NDF intake of crossbred Santa Ines sheep. Contrasting with these results, Runyan and Bader (1994) reported that providing water with salinity levels above 8.0 to $11.0 \mathrm{dS} / \mathrm{m}$ to ruminants, including goat and sheep, should be restricted. It should be noted that the diet offered to the animals was common among treatments, i.e., the solid diet contained similar NDF levels, which did not result in differences in the DM and NDF intakes.
The feeding and rumination efficiencies, expressed in $\mathrm{g} \mathrm{DM} / \mathrm{h}$, presented increasing linear behavior as the salinity of the water increased, although the solid diet offered to the animals was similar among all treatments, containing the same dry matter concentration. The results obtained may be attributed to the water salinity levels, since, according to Potter (1972), Merino sheep fed hay along with consumption of saline water with $1.3 \%$ $\mathrm{NaCl}$ presented significant reduction in the dry matter present in the whole rumen content, and no change in metabolic activity, increasing the flow of the fluid and not the flow of the total digesta without affecting the degradation of solid particles of the diet. These same authors also observed, when the sheep were fed a pelletized diet and water containing $1.3 \% \mathrm{NaCl}$, that the results showed 
a significant drop in the dry matter of the whole rumen content, which was associated with an increase of $68 \%$ in the flow of the fluid, increasing the passage rate of the total digesta of the animals.

The rumination efficiency in $\mathrm{g} \mathrm{NDF} / \mathrm{h}$ was quadratically affected by the different salinity levels studied (Table 4). As the NDF level in the diet was elevated, the use efficiency of these fractions (feed and rumination efficiencies) also increased, due to the greater difficulty to reduce the particle size, which in turn may cause the feed intake to reduce (CARVALHO et al., 2006).

The variables grams of DM per cud and grams of NDF per cud were quadratically affected by the experimental treatments, demonstrating that these two variables are not influenced by DM intake and by rumination efficiency given that they behaved in different manners among the studied treatments.

The variables number of cuds per day, number of chews per cud and chewing time per cud had quadratic effects under the different treatments studied. With regard to the number of cuds per day, the sheep fed water with $640 \mathrm{mg} / 1$ presented higher number of cuds per day in relation to the other animals, which received water with 3,$188 ; 5,740$; and $8,326 \mathrm{mg} / 1$. From the level of $3,188 \mathrm{mg} / \mathrm{l}$ of total dissolved solids, as the water salinity increased, the number of cuds per day increased as well, but not exceeding the average observed at the level of 640 $\mathrm{mg} / \mathrm{l}$ total dissolved solids in the water. However, there was lower dilution of the ruminal fluid in the treatment with $640 \mathrm{mg} / \mathrm{l}$. In the other treatments, there was greater dilution of the ruminal fluid of the animals, precisely because of the greater water intake as the water salinity was increased (Table 5).

Table 5. Total chewing time (TCT), number of cuds per day (NCD), number of cud chews per day (NCCD), number of chews per cud (NCC), chewing time per cud (CTC), number of daily meals (NDM) and average duration of each meal (DEM) of experimental sheep.

\begin{tabular}{lccccccc}
\hline \multirow{2}{*}{ Variable } & \multicolumn{3}{c}{ Total dissolved solids (mg/l) } & Effect & $\mathrm{R}^{2}$ & CV (\%) \\
\cline { 2 - 5 } $\begin{array}{l}\text { TCT } \\
\text { (h/day) }\end{array}$ & 12.07 & 11.38 & 12.28 & 11.45 & $\mathrm{NS}^{1}$ & $\mathrm{NS}$ & 10.59 \\
$\begin{array}{l}\text { NCD } \\
\text { (no./ day) }\end{array}$ & 561.81 & 458.04 & 459.26 & 495.05 & $\mathrm{Q}^{2,3}$ & 0.96 & 10.50 \\
$\begin{array}{l}\text { NCCD } \\
\text { (no./ day) }\end{array}$ & 32.517 .42 & 31.575 & 31.905 & 28.811 .84 & $\mathrm{NS}$ & $\mathrm{NS}$ & 15.53 \\
$\begin{array}{l}\text { NCC } \\
\text { (no./cud) }\end{array}$ & 57.18 & 69.71 & 70.25 & 58.45 & $\mathrm{Q}^{4}$ & 0.99 & 16.47 \\
$\begin{array}{l}\text { CTC } \\
\text { (no./cud) }\end{array}$ & 45.98 & 50.74 & 57.69 & 50.19 & $\mathrm{Q}^{5}$ & 0.80 & 11.22 \\
$\begin{array}{l}\text { NDM } \\
\text { (no./ day) }\end{array}$ & 5.88 & 5.88 & 5.96 & 5.83 & $\mathrm{NS}$ & $\mathrm{NS}$ & 18.24 \\
$\begin{array}{l}\text { DEM } \\
\text { (min) }\end{array}$ & 34.30 & 33.92 & 34.58 & 35.91 & $\mathrm{NS}$ & $\mathrm{NS}$ & 9.76 \\
\hline
\end{tabular}

${ }^{1}$ Not significant. ${ }^{2}$ Quadratic effect.

${ }^{3} \mathrm{Q}=2.1806 \mathrm{x}^{2}-35.505 \mathrm{x}+591.61 .{ }^{4} \mathrm{Q}=-0.3645 \mathrm{x}^{2}+5.2372 \mathrm{x}+52.14 .{ }^{5} \mathrm{Q}=-0.1916 \mathrm{x}^{2}+3.1714 \mathrm{x}+42.168$

According to Potter (1972), when sheep are there is increase in the passage rate of the rumen offered water with $\mathrm{NaCl}$ concentrations of $1.3 \%$, fluid, which consequently results in increased feed 
intake. Besides, there may be effects associated with osmolarity, which results in increased fluid rate. In the present study, it was observed that the water salinity can increase the passage rate of the ruminal fluid, affecting the variables number of cuds per day, number of chews per cud and chewing time per cud.

The number of daily meals and the average duration of each meal did not show effects regarding the level of salinity in the water fed to these animals, which can be associated with the animals remaining confined and being fed twice daily. This is in agreement with the findings of Pereira et al. (2004), who stated that confined ruminants fed two times a day have two mean meals after the supply of the diet, which last from one to three hours, in addition to the variable number of small meals in between them.

Increasing linear behavior was observed for the frequency of water intake, i.e., as the salinity of the water increased, its consumption did as well, which can be explained by the fact that under less toxic salts in the water, animals can increase their water ingestion (Table 6).

Table 6. Average daily number of times drinking water, urinating and defecating by experimental sheep.

\begin{tabular}{lccccccc}
\hline \multirow{2}{*}{ Variable } & \multicolumn{3}{c}{ Total dissolved solids (mg/l) } & \multirow{2}{*}{ Effect } & \multirow{2}{*}{$\mathrm{R}^{2}$} & \multirow{2}{*}{ CV (\%) } \\
\cline { 2 - 5 } & 640 & 3,188 & 5,740 & 8,326 & & & \\
\cline { 2 - 5 } Water intake & 3.17 & 3.88 & 3.92 & 4.13 & $\mathrm{~L}^{1,3}$ & 0.81 & 36.99 \\
Urination & 8.38 & 9.17 & 11.33 & 10.88 & $\mathrm{~L}^{4}$ & 0.79 & 25.66 \\
Defecation & 9.54 & 8.17 & 9.75 & 8.71 & $\mathrm{NS}^{2}$ & $\mathrm{NS}$ & 23.13 \\
\hline
\end{tabular}

${ }^{1}$ Linear effect. ${ }^{2}$ Not significant.

${ }^{3} \mathrm{~L}=0.073 \mathrm{x}+3.264 .{ }^{4} \mathrm{~L}=0.2415 \mathrm{x}+8.2495$.

Similar behavior to that found in this study was observed by Wilson (1966), who evaluated the effect of different concentrations of salts in the diet and water fed to Merino sheep and observed increase in the intake of water when it contained greater concentrations of salts $(2 \%)$, due to the higher volume required to excrete the salts. Assad and El-Sherif (2002), however, working with sheep and camels in Egypt fed water with 280; 7,650; and $13,535 \mathrm{ppm}$ of total dissolved solids found that both species increased water intake as the concentration of salts in the water was elevated, but the camels had lower relative average water intake $(\mathrm{ml} / 100 \mathrm{~kg}$ body weight) than the sheep.

As can be observed in Table 6, for the defecation frequency there was no significant difference among the animals receiving the different salinity levels. However, the number of urinations increased linearly among the treatments, which might have been caused by the mechanism of mineral excretion via the urine, in which animals excrete more urine if they ingest water with lower toxic minerals (chloride, bicarbonates and carbonates), which will allow for stability in the total amount of water in the body of the animals. Therefore, this increase in the frequency of urination as the levels of total dissolved solids in the water increased is explained by the attempt of the animal to maintain its homeostasis. However, alteration in urine excretion was probably caused by increase in the ingestion of water with greater concentrations of ions, which quenched their thirst as well as increased the blood flow in the kidneys in order to eliminate large concentrations of sodium and keep the total amount of water in the body and electrolytes in the animal organism relatively constant (REECE, 2006). 
According to Araújo et al. (2010), urine is an important vehicle through which water-soluble products from the metabolism can be excreted. Usually, when diets rich in protein and mineral are offered to animals, the urine flow tends to be higher.

\section{Conclusions}

Different levels of total dissolved solids (640, $3,188 ; 5,740$; and $8,326 \mathrm{mg} / \mathrm{l})$ in the water fed to sheep do not cause changes in their ingestive behavior. Water up to $8,326 \mathrm{mg}$ TDS/ 1 can be an alternative strategic and seasonal use for watering crossbred sheep Santa Ines created in the semiarid region of Northeast Brazil.

\section{References}

ABIJAOUDE, J. A.; MORANDFEHR, P.; TESSIER, J.; SCHMIDELY, Ph.; SAUVANT, D. Diet effect on the daily feeding behaviour, frequency and characteristics of meals in dairy goats. Livestock Production Science, v. 64 , n. 1, p. 29-37, 2000.

ARAÚJO, G. G. L de; VOLTOLINI, T. V.; CHIZZOTTI, M. L.; TURCO, S. H. N.; CARVALHO, F. F. R. Water and small ruminant production. Revista Brasileira de Zootecnia, Visçosa, v. 39, p. 326-336, 2010. Suplemento.

ASSAD, F.; EL-SHERIF, M. M. A. Effect of drinking saline water and feed shortage on adaptive responses of sheep and camels. Small Ruminant Research, v. 45, n. 3, p. 279-290, 2002.

ASSOCIATION OF OFFICIAL ANALYTICAL CHEMISTRY - AOAC. Official Methods of Analysis. $15^{\text {th }}$ ed. Arlington: AOAC International, 1990.

BOYLES, S. Livestock and water. The Ohio State University Extension, 2009. 18 p. Available at: $<$ http:// www.ag.ohiostate.edu/ beef/library/water.html>. Accessed at: five may 2013.

BÜRGER, P. J.; PEREIRA, J. C.; QUEIROZ, A. C.; SILVA, J. F. C.; VALADARES FILHO, S. C.; CECON, P. R.; CASALI, A. D. P. Comportamento ingestivo em bezerros holandeses alimentados com dietas contendo diferentes níveis de concentrado. Revista Brasileira de Zootecnia, Viçosa, MG, v. 29, n. 1, p. 236-242, 2000.
CARVAlHO, G. G. P.; PIRES, A. J. V.; SILVA, F. F.; VELOSA, C. M.; SILVA, R. R.; SILVA, H. G. O.; BONOMO, B.; MENDONÇA, S. S. Comportamento ingestivo de cabras leiteiras alimentadas com farelo de cacau ou torta de dendê. Pesquisa Agropecuária Brasileira, Brasília, v. 39, n. 9, p. 919-925, set. 2004.

CARVALHO, S.; RODRIGUES, M. T.; BRANCO, R. H.; RODRIGUES, C. A. F. Comportamento ingestivo de cabras Alpinas em lactação alimentadas com dietas contendo diferentes níveis de fibra em detergente neutro proveniente da forragem. Revista Brasileira de Zootecnia, Viçosa, MG, v. 35, n. 2, p. 562-568, 2006.

COMPANHIA DE PESQUISA DE RECURSOS MINERAIS - CPRM. Eventos críticos. Brasília: [s.n], 2012. Disponível em: <http://www.cprm.gov.br/ publique/cgi/cgilua.exe/sys/start.htm?sid=35>. Acesso em: 6 jan. 2013.

EMPRESA BRASILEIRA DE PESQUISA AGROPECUÁRIA- EMBRAPA. Dados meteorológicos. Petrolina, PE, 2011. Disponível em: <http://www.cpatsa. embrapa.br:8080/servicos/dadosmet/ceb-dia.html>. Acesso em: 5 may 2013.

LICITRA, G.; HERNANDEZ, T. M.; VAN SOEST, P. J. Standardization of procedures for nitrogen fractionation of ruminant feeds. Animal Feed Science and Technology, Amsterdam, v. 57, n. 4, p. 347-358, 1996.

MARKWICK, G. Water requirements for sheep and cattle. Profitable \& Sustainable primary industry, 2007. Available at: $<$ http://www.dpi.nsw.gov.au $>$. Accessed at: 9 july 2013

MENDONÇA, S. S.; CAMPOS, J. M. S.; VALADARES FILHO, S. C.; VALADARES, R. F. D.; SOARES, C. A.; LANA, R. P.; QUEIROZ, A. C.; ASSIS, A. J.; PEREIRA, M. L. A. Comportamento ingestivo de vacas leiteiras alimentadas com dietas à base de canade-açúcar ou silagem de milho. Revista Brasileira de Zootecnia, Viçosa, MG, v. 33, n. 3, p. 7 23-728, 2004.

MERTENS, D. R. Analysis of fiber in feeds and its use in feed evaluation and ration formulation. In: SIMPÓSIO INTERNACIONAL DE RUMINANTES, 1992, Lavras. Anais... Lavras: Sociedade Brasileira de Zootecnia, 1992. p. 1-32.

MOREIRA, J. N.; LIRA, M. A.; SANTOS, M. V. F.; FERREIRA, M. A.; ARAÚJO, G. G. L.; FERREIRA, R. L C.; SILVA, G. C. Caracterização da vegetação de Caatinga e da dieta de novilhos no Sertão de Pernambuco. Pesquisa Agropecuária Brasileira, Brasília, v. 41, n. 11, p. 1643-1651, 2006. 
NATIONAL RESEARCH COUNCIL - NRC. Nutrient requeriments of small ruminants: Sheep, goats, cervids, and new world camelids. Washington: National Academic Press, 2007. p. 244265.

MENDES NETO, J.; CAMPOS, J. M. S.; VALADARES FILHO, S. C.; LANA, R. P.; QUEIROZ, A. C.; EUCLYDES, R. F. Comportamento ingestivo de novilhas leiteiras alimentadas com polpa cítrica em substituição ao feno de capim-tifton 851. Revista Brasileira de Zootecnia, Viçosa, MG, v. 36, n. 3, p. 618-625, 2007.

NOMURA, T. M.; ÍTAVO, C. C. B. F.; WALKER, C. C.; HEIMBACH, N. S.; MIOTTO, G. P.; CARDIM, C. M.; BALDASSINI, W. A.; MELLO, G. K. A. Comportamento ingestivo de ovinos. In: MOSTRA CIENTÍFICA DE MEDICINA VETERINÁRIA E ZOOTECNIA DA FACULDADE DE MEDICINA VETERINÁRIA E ZOOTECNIA DA UNIVERSIDADE FEDERAL DE MATO GROSSO DO SUL, 1., 2008, Campo Grande. Anais... Campo Grande: Universidade Federal de Mato Grosso do Sul, 2008.

PEREIRA, E. S.; ARRUDA, A. M. V.; MIZUBUTI, I. Y. Comportamento ingestivo de vacas em lactação alimentadas com diferentes fontes de volumosos conservados. Semina: Ciência Agrárias, Londrina, v. 25, n. 2, p. 159-166, 2004.

POLLI, V. A.; RESTLE, J.; SENNA, D. B.; ALMEIDA, S. R. S. Aspectos relativos à ruminação de bovinos e bubalinos em regime de confinamento. Revista Brasileira de Zootecnia, Viçosa, MG, v. 25, n. 5, p. 987-993, 1996.

PORTO, E. R.; AMORIM, M. C. C.; ARAÚJO, O. J.; SILVA JUNIOR, L. G. A. Aproveitamento dos rejeitos da dessalinização. In: SIMPÓSIO SOBRE CAPTACÃO DE ÁGUA DE CHUVA NO SEMIARIDO BRASILEIRO,Petrolina, 1997. Anais... Petrolina: EMBRAPA-CPATSA/IRPAA/IRCSA, 1997. p. 51-57.
POTTER, B. J. The influence of previous salt ingestion on the renal function of sheep subjected to intravenous hypertonic saline. Journal Physiology, v. 194, n.2, p. 435-455, 1972.

REECE, W. O. Fisiologia dos animais domésticos. Revisão técnica Newton da Cruz Rocha; Tradução Cid Figueiredo, Ildilia Ribeiro Vanzellotti, Ronaldo Frias Zanon. 12. ed. Rio de Janeiro: Guanabara Koogan, 2006.

RUNYAN, C.; BADER, J. Water quality for livestock and poultry. In: Water quality for agriculture. FAO Irrigation and drainage papers. Rome: FAO, 1994. $\mathrm{n}$. $29,186 \mathrm{p}$.

SOUZA, E. J. O.; GUIM, A.; BATISTA, A. M. G.; ALBUQUERQUE, D. B.; MONTEIRO, C. C. F.; ZUMBA, E. R. F.; TORRES, T. R. Comportamento ingestivo e ingestão de água em caprinos e ovinos alimentados com feno e silagem de Maniçoba. Revista Brasileira de Saúde e Produção Animal, Salvador, v. 11, n. 4, p. 1056-1067, 2010.

STATISTICAL ANALYSIS SYSTEM - SAS. User's guide. Cary: SAS Institute, 2003. 2694 p.

VALADARES FILHO, S. C.; MAGALHÃES, K. A.; ROCHA JÚNIOR, V. R.; MACHADO, P. A. S.; CHIZZOTTI, M. L.; AMARAL, H. F.; CAPELLE, E. R. Tabelas brasileiras de composição de alimentos para bovinos. 2. ed. Viçosa, MG: UFV, Suprema Gráfica Ltda., 2006. $329 \mathrm{p}$.

WILSON, A. D. The tolerance of sheep to sodium chloride in food or drinking water. Australian Journal of Agricultural Research, v. 17, n. 4, p. 503-514, 1966. 